$1-1-1955$

\title{
Ammonification and nitrification in a strip mine spoil
}

\author{
H. A. Wilson
}

Gwendolyn Stewart

Follow this and additional works at: https://researchrepository.wvu.edu/ wv_agricultural_and_forestry_experiment_station_bulletins

\section{Digital Commons Citation}

Wilson, H. A. and Stewart, Gwendolyn, "Ammonification and nitrification in a strip mine spoil" (1955). West Virginia Agricultural and Forestry Experiment Station Bulletins. 379T.

https://researchrepository.wvu.edu/wv_agricultural_and_forestry_experiment_station_bulletins/634 @ WVU. It has been accepted for inclusion in West Virginia Agricultural and Forestry Experiment Station Bulletins by an authorized administrator of The Research Repository @ WVU. For more information, please contact ian.harmon@mail.wvu.edu. 
West Virginia University Libraries

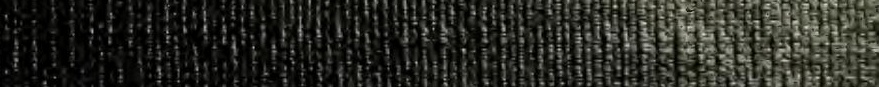

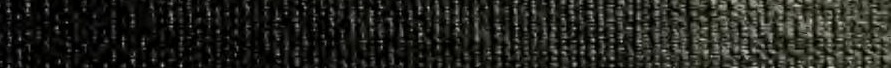

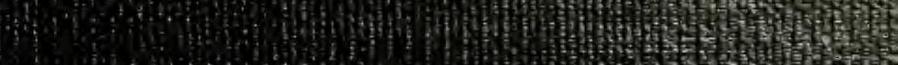

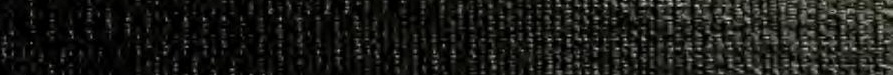

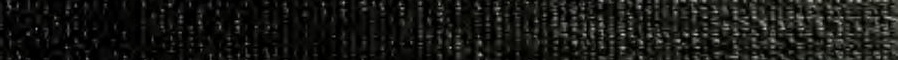
H: 
Digitized by the Internet Archive in 2010 with funding from Lyrasis Members and Sloan Foundation 


\section{BULLETIN 379T June 1955}

\section{Ammonification and Nitrification} In a Strip Mine Spoil 


\section{THE AUTHORS}

Harold A. Wilson is Associate Bacteriologist at the West Virginia University Agricultural Experiment Station and Associate Professor of Bacteriology in the College of Agriculture, Forestry, and Home Economics. Gwendolyn Stewart was Assistant in Bacteriology at the West Virginia University Agricultural Experiment Station.

WEST ViRginia UNIVERSITY

Agricultural Experiment Station

College of Agriculture, Forestry, and Hone Economics

H. R. VARNeY, DiRECTOR

MORGANTOWN 


\section{Ammonification and Nitrification In a Strip Mine Spoil}

\section{H. A. WILSON and GWENDOLYN STEWART}

THE revegetation of spoils which result from strip or open pit mining of coal is a relatively new endeavor. Most of our knowledge dealing with revegetation is based upon work done on recognized soil types, and not upon a spoil, which is a mixture of soil and parent material such as limestone, sandstone, shale, and glacial till.

When vegetation is once established its continued presence will depend upon numerous physical and chemical factors. One of the important chemical factors is a continuous supply of nitrogen. Since only a few species are capable of utilizing nitrogen in the ammonium form satisfactorily, the nitrate form is the most important.

Ammonification and nitrification in the soil are biological processes. Both are necessary in transforming the nitrogen of organic materials first to ammonium and then to the nitrite and finally to the nitrate form. Knowledge concerning these processes in spoil is limited.

Laboratory studies of the ammonification of various organic nitrogenous compounds and the nitrification of ammonium sulphate in spoil samples from a single area are reported in this bulletin.

The ammonification process is brought about by several groups of microorganisms. Many fungi and actinomycetes, as well as numerous aerobic and anaerobic bacteria, according to Waksman and Starkey (14), are capable of liberating ammonium nitrogen from various organic nitrogenous compounds.

Since many fungi, actinomycetes, and bacteria are capable of carrying out the ammonification process, the soil reaction, within limits, will have little effect upon this action. Ammonification in an acid environment would be by microorganisms tolerant of acid conditions. Muntz and Coudon, and Marchal, as reported by Russell (9), showed that some species of Mucor, Fusarium, Aspergillus and Cephalothecium, and other soil fungi were active ammonifiers in acid soil. Conversely, bacteria and actinomycetes play the major role in ammonium nitrogen formation in the alkaline soils of the arid region.

Cornfield (2) reported that the accumulation of ammonium nitrogen was generally high in acid and low in neutral and alkaline soils. From 
a study of some Connecticut soils having $\mathrm{pH}$ values of 5.30 and 5.50 , Dorsey (5) found that when $\mathrm{CaCO}_{3}$ was added the ammonifying power of the soil organisms increased.

According to Waksman and Starkey (14), some organic nitrogenous compounds are more readily decomposed than others; also, microorganisms vary in their ability to transform nitrogen compounds. Pulley (8) also showed that microorganisms differ in their ammonifying power.

Nitrification, the oxidation of ammonium nitrogen to nitrite and nitrate, is a function of a certain few autotrophic bacteria. Consequently, this process is limited by some conditions which would have little or no effect upon the process of ammonification. Five genera of bacteria, Nitrosomonas, Nitrosocystis, Nitrospira, Nitrosococcus, and Nitrosogloea, possess the ability of oxidizing ammonium to nitrite (13), while only the bacterial genus, Nitrobacter, seems capable of oxidizing the nitrite to nitrate. However, not all of the nitrite-forming bacteria are found in all soils.

Although different workers have reported slightly different degrees of acidity below which the nitrification process fails to function, it seems that a $\mathrm{pH}$ value of $3.7-4.0$ (13) is the minimum. The process has an optimum $\mathrm{pH}$ of 6.5 to 7.5

Cornfield (2), and others $(6,15)$, have noted that the addition of a neutralizing material, as $\mathrm{CaCO}_{3}$, to acid soils favors the nitrification process. Coville (3) concluded that nitrification is active in acid soils around lime concentrations but that the production of nitrate in acid soil is low. Stevenson and Chase (10) also found that the addition of $\mathrm{CaCO}_{3}$ to an acid soil increased the nitrification rate, but they did not believe that the increase was due entirely to the decrease in the $\mathrm{H}$-ion concentration. They concluded that it could be due to a stimulating effect of the $\mathrm{CaCO}_{3}$ upon the nitrifiers or to an increase in numbers of the nitrifying bacteria. This last view agrees with the findings of Allison and Sterling (1), and of Walker, Thorne and Brown (16).

\section{Materials and Methods}

Spoil from the Canyon area, near Morgantown, West Virginia, was used in this work. Previously, a part of this area had been limed, fertilized, and seeded to grasses and legumes by Tyner and associates $(11,12)$. An adjacent area of the spoil was untreated and remained devoid of plant growth. Near-by soil which appeared not to have been modified by the stripping operations was available as a control.

Composite bulk samples of the nonvegetated spoil, the vegetated spoil, and the undisturbed soil were collected. These samples were immediately passed through a quarter-inch wire mesh to remove bits of 
rock, coal and shale and then brought to the laboratory and spread out until air dry.

One-hundred-gram portions (oven-dry basis) of the samples were weighed into $250-\mathrm{ml}$. beakers. The samples were properly divided and the following investigations made: (a) ammonification of different organic nitrogenous compounds, with and without added $\mathrm{Ca}(\mathrm{OH})_{2}$; (b) the ammonification rate of the samples when supplied with urea, peptone, and egg albumin; and (c) the nitrification of $\left(\mathrm{NH}_{4}\right)_{2} \mathrm{SO}_{4}$ when added to the samples with and without $\mathrm{Ca}(\mathrm{OH})_{2}$.

After the various materials had been thoroughly mixed into the samples, distilled water was added to bring the moisture content of each sample to 45 per cent of its water-holding capacity. The beakers were then placed in an incubator room maintained at $25^{\circ} \pm 1^{\circ} \mathrm{C}$. Moisture lost during the incubation period was restored at semi-weekly intervals by bringing the samples back to their original weight by the addition of distilled water. The samples were thoroughly stirred each week.

At the end of an incubation period the entire sample was removed from its beaker and thoroughly mixed. An amount of the sample equivalent to $10 \mathrm{gm}$. (oven-dry basis) was removed and placed in a small beaker for $\mathrm{pH}$ determination. Sufficient water was added to make a soil:water ratio of $1: 1.5$ and after standing, with frequent shakings for one hour, the $\mathrm{pH}$ was determined, using a glass electrode. The remainder of the sample was placed in a quart milk bottle and $2 \mathrm{~N} \mathrm{KCl}$ (acidified with $\mathrm{HCl}$ to $\mathrm{pH}$ 1.5) was added as an extracting fluid. The bottle and its contents were shaken on a Precision equipoise shaker for 30 minutes and the contents filtered through two E \& D No. 613 filter papers in a Büchner funnel.

Ammonium and nitrate nitrogen were determined upon an aliquot of the filtrate. The ammonium nitrogen was determined by the $\mathrm{MgO}$ method and the nitrate nitrogen by the DeVarda's alloy method. All data are reported as ammonium or nitrate nitrogen in terms of milligrams of nitrogen per $100 \mathrm{gm}$. of spoil on an oven-dry basis. Each result is the average of duplicate samples. Each sample was an independent sample, therefore the results are more accurate than an average obtained from two aliquots from the same sample.

The theoretical amount of $\mathrm{Ca}(\mathrm{OH})_{2}$ required to neutralize each sample was determined from the buffer curves developed according to the method of Dunn (4).

To eliminate needless repetition, the term spoil often will include the soil sample. The samples from the nonvegetated part of the spoil area will be designated as "non-vegetated"; from the vegetated part as "vegetated" and the soil as "undisturbed." Individually or collectively these terms will be referred to as treatment. 


\section{Results}

AMMONIFICATION OF VARIOUS NITROGENOUS

\section{ORGANIC SUBSTANCES}

The organic nitrogen sources used in studying ammonification by the nonvegetated, vegetated, and undisturbed spoils were urea, asparagine, peptone, casein hydrolysate, tryptone, and egg albumin. Each nitrogen source was added to the spoil samples to supply $100 \mathrm{mg}$. of nitrogen per $100 \mathrm{gm}$. of spoil. Two series of samples were run. In one series the $\mathrm{pH}$ of the spoil was unaltered. In the other the theoretical amount of $\mathrm{Ca}(\mathrm{OH})_{2}$ required to neutralize $(\mathrm{pH} 7.0)$ the spoil was added to the samples. This quantity was determined from titration values shown in Figure 1.

The results obtained after seven days incubation at $25^{\circ} \mathrm{C}$ are tabulated in Table 1 and shown graphically in Figure 2.

In the nonvegetated spoil asparagine was ammonified more readily than any other nitrogenous source used, and egg albumin the least

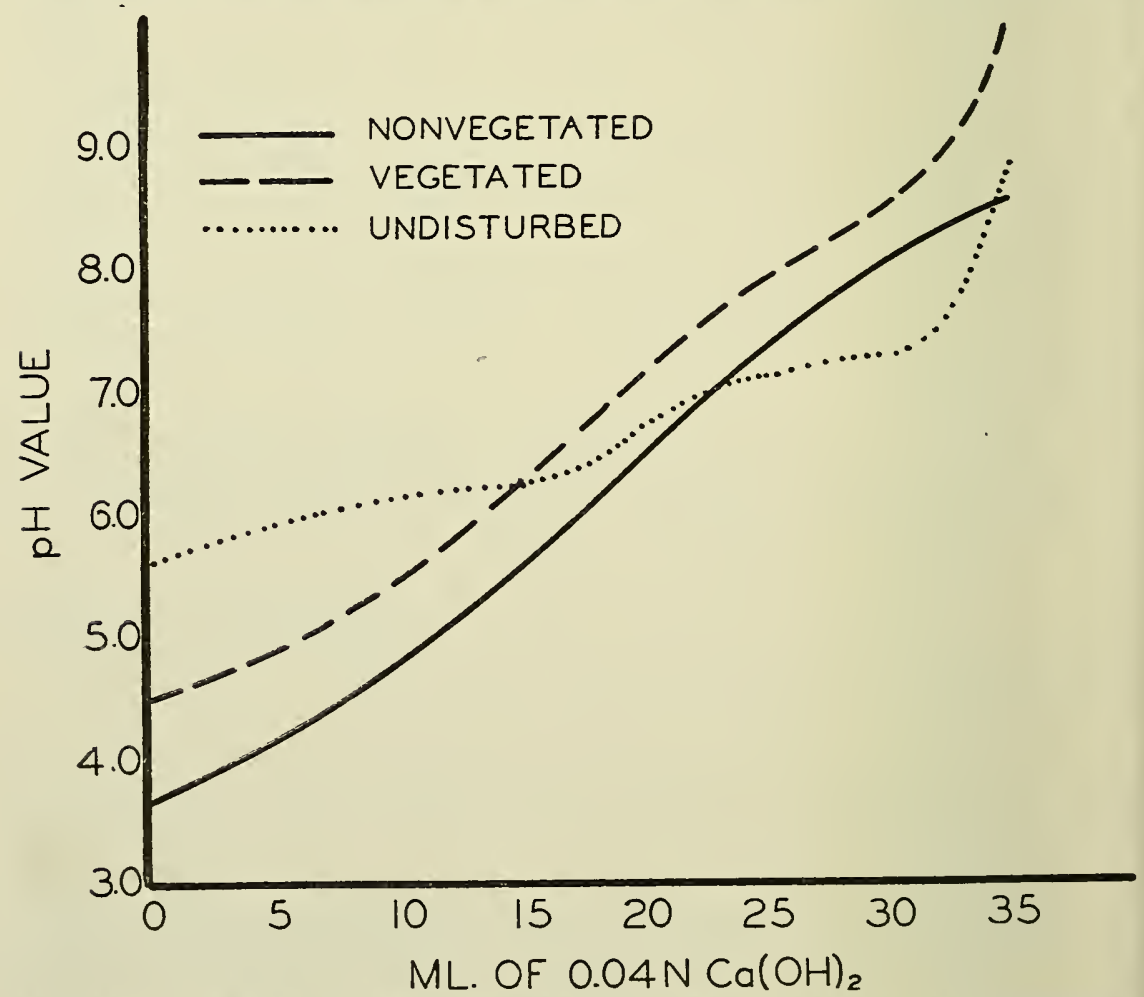

FIGURE 1. Buffer Curves of the Canyon Area Nonvegetated and Vegetated Spoils and Undisturbed Soil. 


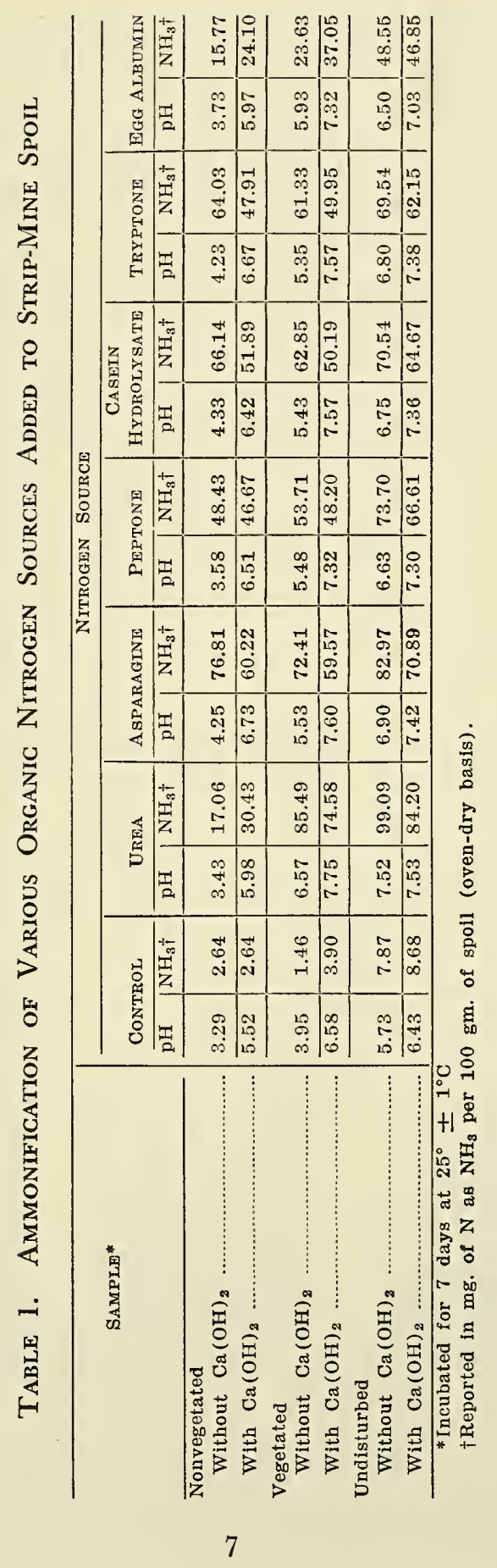


readily. This was true with or without the added $\mathrm{Ca}(\mathrm{OH})_{2}$, even though at the end of seven days the $\mathrm{pH}$ of the spoil was 4.25 without $\mathrm{Ca}(\mathrm{OH})_{2}$ and 6.73 with $\mathrm{Ca}(\mathrm{OH})_{2}$.

In most instances the addition of $\mathrm{Ca}(\mathrm{OH})_{2}$ resulted in less ammonium nitrogen being recovered. The greatest reduction occurred in the nonvegetated samples with casein hydrolysate and tryptone.

\section{Rate of Ammonification}

The preceding data indicated differences in the amount of ammonium as nitrogen obtained from these spoil samples after a given period of incubation but no indication as to the rate of the ammonification process. Determinations of rate of ammonium nitrogen production were made on another series of samples, using three nitrogen sources, egg albumin, peptone and urea. Since it was evident from the data in Table 1 that the addition of $\mathrm{Ca}(\mathrm{OH})_{2}$ depressed the amount of ammonium nitrogen recovered, none was added to this series. All other conditions were the same. Ammonium as nitrogen was determined on samples every two days. These results are given in Table 2 and shown graphically in Figure 3.

The data show that the rate of ammonification of egg albumin, peptone and urea by the nonvegetated spoil is slower than the corresponding rates for the vegetated and the undisturbed spoils. The curves representing the rate of ammonification of egg albumin and peptone by the vegetated and the nonvegetated spoils are roughly parallel, and the amount of nitrogen represented is not greatly different. However, the curve representing the rate of ammonification of these

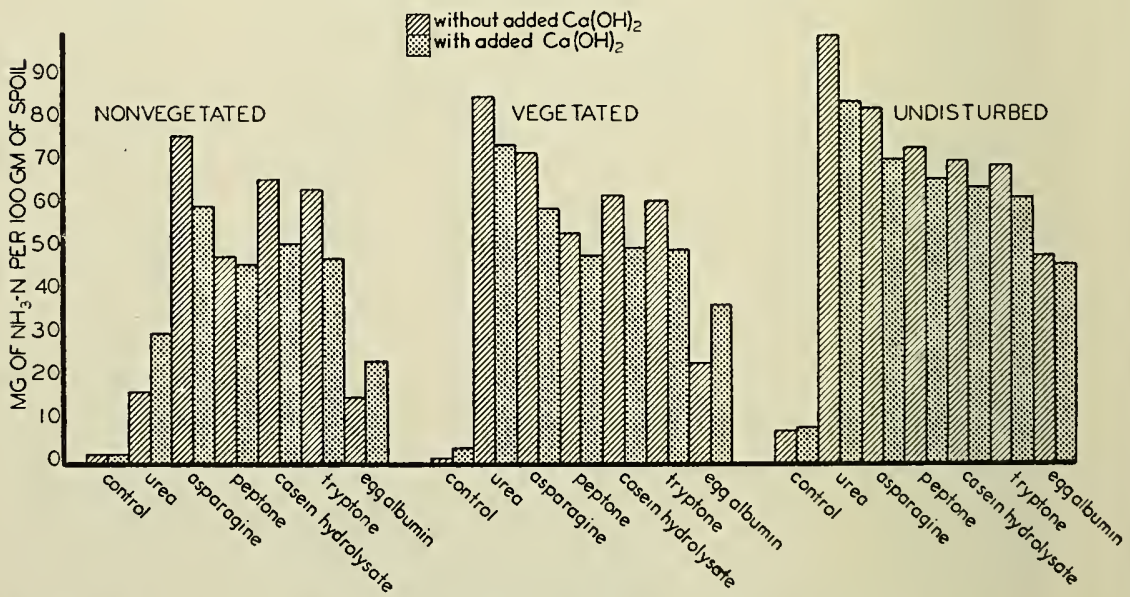

FIGURE 2. Ammonification of Various Organic Nitrogenous Materials Added to Spoil. (Incubated at $25 \pm 1^{\circ} \mathrm{C}$.) 


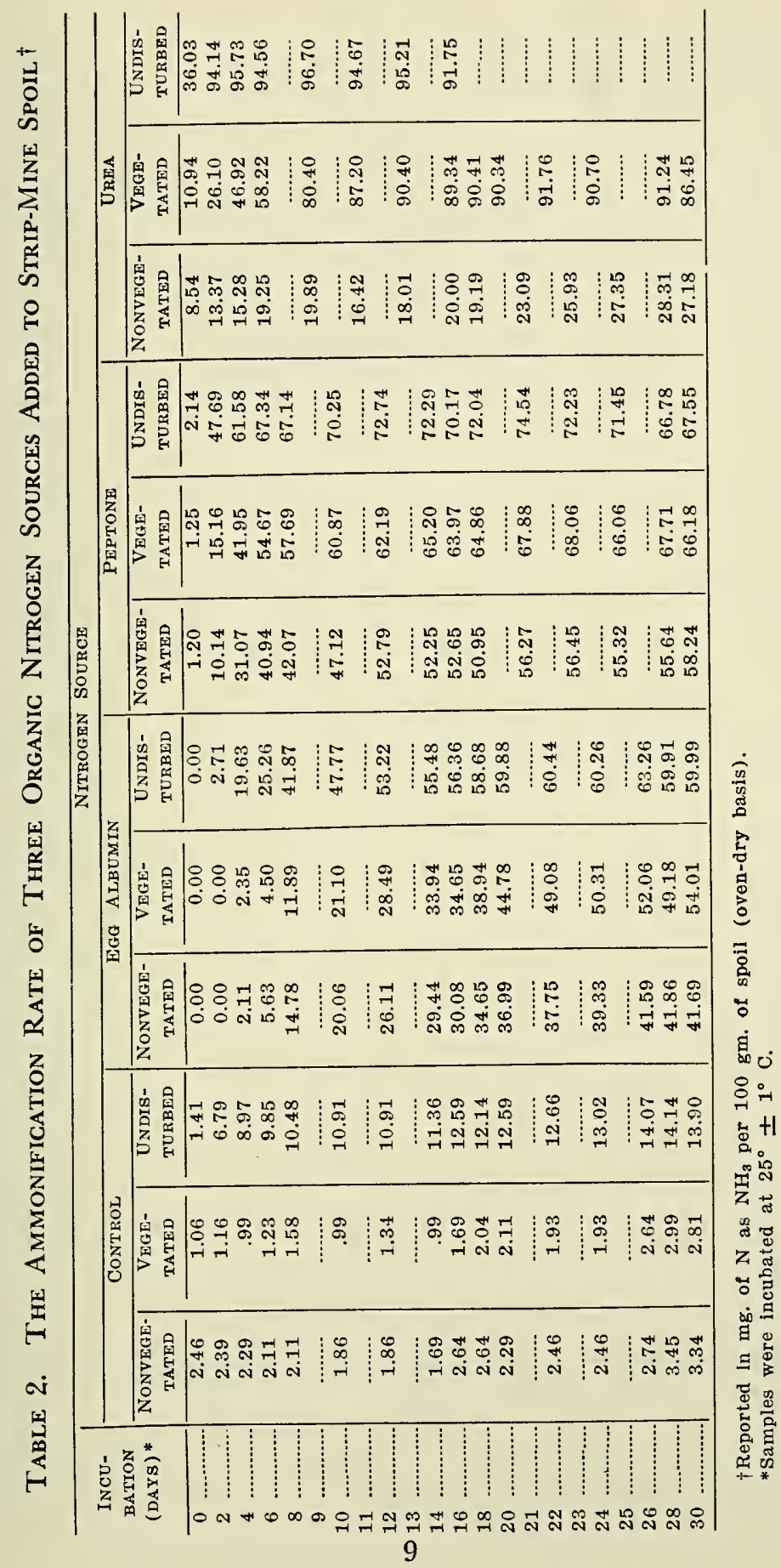


two substances by the undisturbed soil is different in shape and represents a considerably greater amount of nitrogen.

The rate of ammonification of urea by the three samples varies greatly. Ammonification of urea by the nonvegetated sample is slow and the amount of ammonium nitrogen eventually liberated is small. The rate of ammonification by the vegetated sample is much more rapid, and the amount of ammonium nitrogen eventually liberated is nearly as great as that of the undisturbed sample. Ammonification of urea by

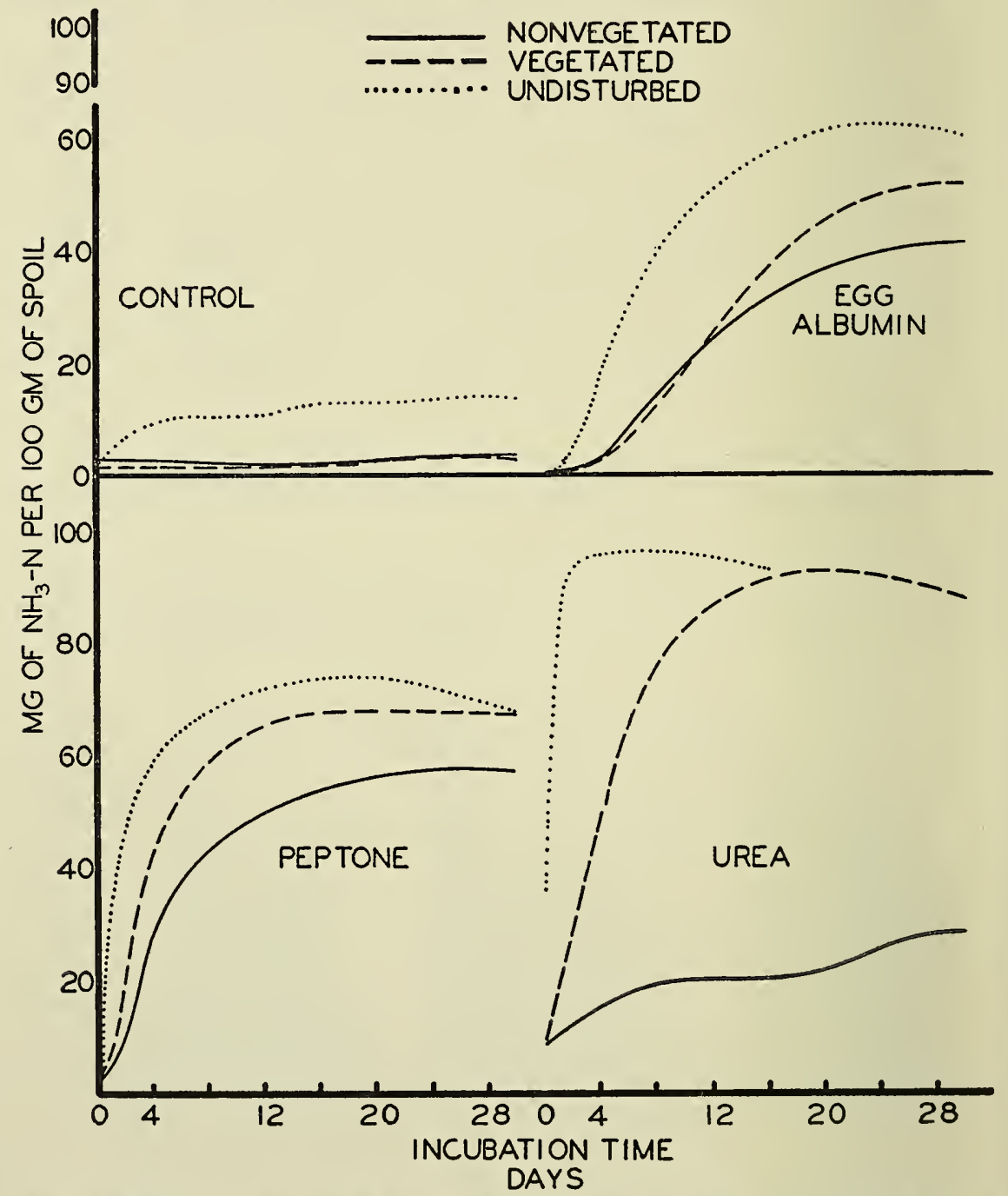

FIGURE 3. The Ammonification Rate of Three Organic Nitrogen Sources Added to Spoil. (Incubated at $25 \pm 1^{\circ}$ C.) 
the undisturbed sample reached its maximum in less than 10 days. After 16 days the amount of ammonium nitrogen began to decrease, so determinations were discontinued.

\section{NITRIFICATION}

Nitrification by the three samples was determined by adding $\left(\mathrm{NH}_{4}\right)_{2} \mathrm{SO}_{4}$, equivalent to $50 \mathrm{mg}$. of nitrogen, to 100 gram samples of spoil and incubating for varying periods of time. Because of the low $\mathrm{pH}$, particularly of the nonvegetated spoil, one series received the theoretical amount of $\mathrm{Ca}(\mathrm{OH})_{2}$ to neutralize the spoil, and the other received no $\mathrm{Ca}(\mathrm{OH})_{2}$ Conditions of incubation were as previously described. The results are shown in Table 3.

It was soon evident that determinations at 5-day intervals would quickly exhaust the number of incubating samples and little information would be obtained since nitrification occurred so slowly. Because of this no fixed time pattern was followed.

After 159 days of incubation, $45.24 \mathrm{mg}$. of ammonium nitrogen were obtained from the nonvegetated spoil without $\mathrm{Ca}(\mathrm{OH})_{2}$. Only traces of nitrate nitrogen were found during the first 35 days of incubation and after that time none. The $\mathrm{pH}$ during the entire incubation period varied; increasing from 3.48 at 0 days to a maximum of 3.73 on the 47 th day and down to 3.55 after 159 days of incubation.

Only traces of nitrate nitrogen were found in the nonvegetated spoil with added $\mathrm{Ca}(\mathrm{OH})_{2}$ until the 97 th day of incubation, but by the 159 th day nitrification of the $\left(\mathrm{NH}_{4}\right)_{2} \mathrm{SO}_{4}$ was definitely taking place. The $\mathrm{pH}$ values of these samples which received $\mathrm{Ca}(\mathrm{OH})_{2}$ ranged from 3.70 at 0 days to 4.58 after 159 days of incubation with two maxima of $\mathrm{pH} 6.20$ after 15 and 35 days of incubation.

Although only $2.21 \mathrm{mg}$. of nitrogen as nitrate were found in the vegetated sample without added $\mathrm{Ca}(\mathrm{OH})_{2}$ after 159 days of incubation, it is probable that nitrate nitrogen was beginning to accumulate. Nitrification of the $\left(\mathrm{NH}_{4}\right)_{2} \mathrm{SO}_{4}$ in the vegetated spoil with added $\mathrm{Ca}(\mathrm{OH})_{2}$ began between the 15 th and the 25 th days of incubation as only 0.37 $\mathrm{mg}$. of nitrate nitrogen were found after 15 days of incubation but 4.05 mg. after 25 days. A gradual increase in the amount of nitrate nitrogen was apparent from 25 through 77 days of incubation; reaching a high of $26.85 \mathrm{mg}$. at that time. This increase in nitrate nitrogen was accompanied by a decrease of ammonium nitrogen, decreasing from 47.26 mg. at 0 days to $12.32 \mathrm{mg}$. after 77 days incubation. No samples were available to continue the determinations for a longer incubation period.

In the undisturbed samples, without added $\mathrm{Ca}(\mathrm{OH})_{2}$, only traces of nitrate nitrogen were found in samples incubated for any period 


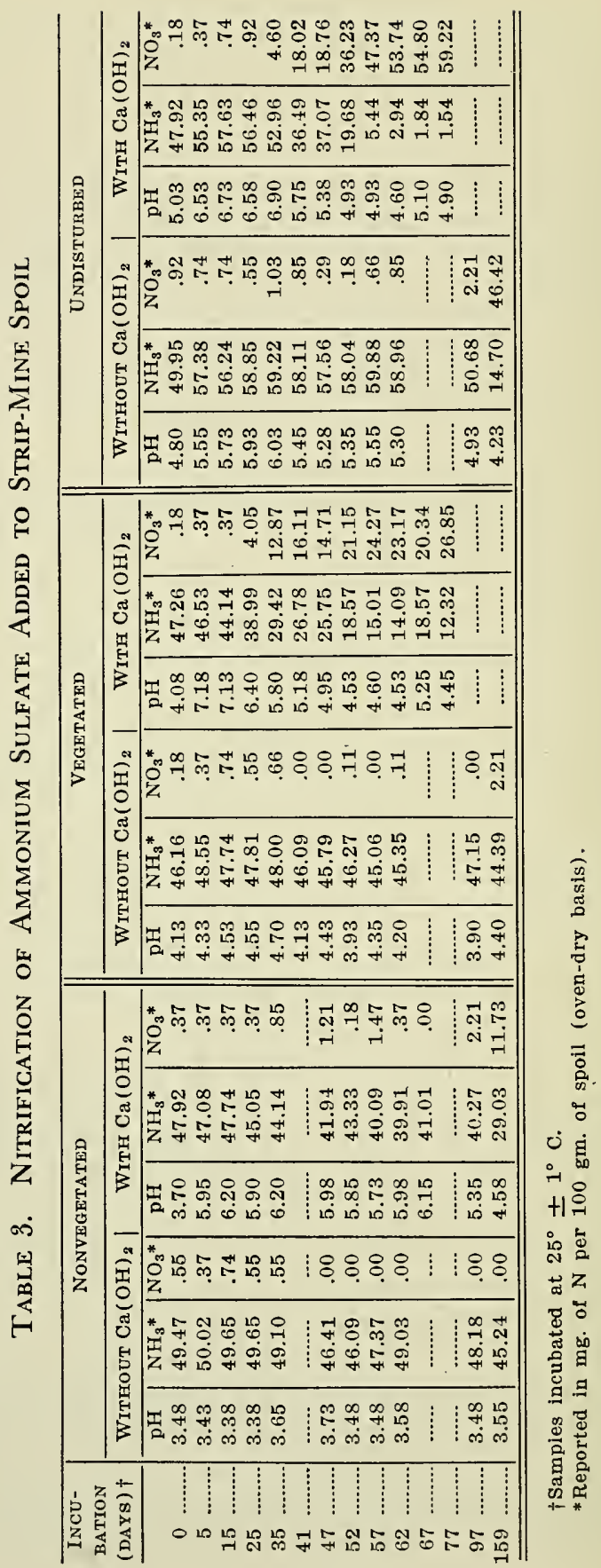


through 62 days. After 97 days of incubation, $2.21 \mathrm{mg}$. of nitrate nitrogen were found, indicating that nitrates were beginning to accumulate. After 159 days of incubation, $46.42 \mathrm{mg}$. of nitrogen as nitrates were found; accompanied by a decrease of ammonium nitrogen from $49.95 \mathrm{mg}$. at 0 days to $14.70 \mathrm{mg}$. after 159 days of incubation.

Nitrification in the undisturbed sample, with added $\mathrm{Ca}(\mathrm{OH})_{2}$, became evident after 35 days incubation and seemed nearly complete after 77 days, as judged from the increase of nitrate and the decrease of ammonium nitrogen.

\section{Discussion}

The transformation of organic nitrogen to ammonium nitrogen from different materials incorporated into an acid spoil occur at varying rates. In the nonvegetated spoil, with a $\mathrm{pH}$ of 3.29 , the availability of the compounds in terms of ammonium nitrogen accumulated in seven days was in the following decreasing order: asparagine, casein hydrolysate, tryptone, peptone, urea, and egg albumin. The addition of the theoretical amount of $\mathrm{Ca}(\mathrm{OH})_{2}$ to neutralize this spoil did not change the order of accumulation, although less ammonium nitrogen accumulated from two of the six sources with added $\mathrm{Ca}(\mathrm{OH})_{2}$.

Under vegetated and undisturbed conditions more ammonium nitrogen was released from urea after seven days incubation than from any other material; asparagine was second in yield and egg albumin last.

In all cases the $\mathrm{H}$-ion concentration decreased as ammonium nitrogen was released from the organic material, and in most cases the sample which contained the largest amount of ammonium nitrogen had the highest $\mathrm{pH}$ value.

The addition of $\mathrm{Ca}(\mathrm{OH})_{2}$ to the spoil probably made conditions favorable for the increase in micrcorganisms, and this may account for the smaller amount of ammonium nitrogen in samples with added $\mathrm{Ca}(\mathrm{OH})_{2}$; apparently some of the ammonium nitrogen had been utilized by the microorganisms.

The nonvegetated spoil appears to be somewhat deficient in those microorganisms capable of transforming the nitrogen of urea to ammonium nitrogen. As shown in Table 2, even after 30 days incubation, only $27 \mathrm{mg}$. of ammonium nitrogen were available. This amount is practically the same as that found after only seven days incubation. On the other hand, urea is readily ammonified in the vegetated and undisturbed samples. It seems apparent that a nonvegetated spoil, as acid as 3.29, is not a favorable environment for these microorganisms.

The nitrogen of peptone is readily transformed into ammonium nitrogen in the nonvegetated, vegetated, and undisturbed samples; the 
transformation was slowest with the nonvegetated sample. Egg albumin, the most difficult of the organic materials to decompose, became rather quickly ammonified after a short lag period. This lag period was approximately six days in the nonvegetated and vegetated samples but only two days in the undisturbed sample.

These data indicate that the availability of ammonium nitrogen from organic nitrogenous materials added to spoil will be satisfactory even at the relatively high $\mathrm{H}$-ion concentrations which exist. If such spoil areas are planted to pine seedlings, the ammonium form of nitrogen will be used (7).

The nitrification data indicate that without a reduction of the $\mathrm{H}$-ion concentration no oxidation of the ammonium to nitrate nitrogen will take place, particularly in the nonvegetated spoil. Even in the vegetated spoil with a somewhat higher $\mathrm{pH}, 4.13$ as compared to 3.48 in the nonvegetated spoil, only $2.21 \mathrm{mg}$. of nitrogen as nitrate was found after 159 days of incubation. This was the same as in the undisturbed sample after 97 days. In the undisturbed soil however, considerable nitrification had taken place within five months. In all three samples, with added $\mathrm{Ca}(\mathrm{OH})_{2}$, nitrification does take place, but at different rates. It has been shown that the number of nitrifiers are low as determined by MPN method (17), even in the undisturbed samples. It is apparent from these data that strongly acid spoils must be limed before the nitrification process will take place. Although such spoils may be supporting vegetation the amount of nitrate formation may be small.

\section{Summary}

A laboratory study of the ammonifying and nitrifying powers of nonvegetated and vegetated spoil samples from one coal strip-mined area were compared with those of samples taken of a near-by soil.

The ammonifying power of the samples was measured after adding urea, asparagine, tryptone, casein hydrolysate, peptone, and egg albumin, equivalent to $100 \mathrm{mg}$. nitrogen per $100 \mathrm{gm}$. of sample, by determining the amount of ammonium nitrogen produced after seven days incubation at $25^{\circ} \mathrm{C}$. The moisture content was maintained at 45 per cent of the samples' water-holding capacity during incubation. Two series of samples were run. One received the theoretical amount of $\mathrm{Ca}(\mathrm{OH})_{2}$ required to neutralize the acidity, and the other received no $\mathrm{Ca}(\mathrm{OH})_{2}$.

All of the nitrogen sources were ammonified in all samples but at varying rates. In the vegetated spoil and soil samples, urea and asparagine were ammonified most rapidly and egg albumin most slowly. In the nonvegetated spoil samples, asparagine was most rapidly am- 
monified but urea was ammonified only slightly more rapidly than egg albumin. In general, the additional $\mathrm{Ca}(\mathrm{OH})_{2}$ resulted in a smaller residue of ammonium nitrogen after incubation.

The ammonification of the urea, peptone, and egg albumin nitrogen was determined at two-day intervals during a 30-day incubation period, when added to the samples of spoil and soil without added $\mathrm{Ca}(\mathrm{OH})_{2}$. The release of ammonium nitrogen from all three sources was slower in the nonvegetated spoil than in the vegetated spoil and undisturbed soil. However, the total amount of ammonium nitrogen released from peptone or egg albumin after 30 days incubation was not greatly different in the nonvegetated and vegetated samples. On the other hand, urea, when added to the nonvegetated spoil, was ammonified not only at a much slower rate than in the vegetated spoil and undisturbed soil samples, but the total amount of ammonium nitrogen found after 30 days incubation was much less.

The nitrifying power of the samples was measured, after adding ammonium sulfate equivalent to $50 \mathrm{mg}$. of nitrogen per $100 \mathrm{gm}$. of sample, by determining the amount of nitrate nitrogen produced after incubating the samples at $25^{\circ} \mathrm{C}$. for varying lengths of time. The samples were maintained at 45 per cent of their water-holding capacity. Because of the low $\mathrm{pH}$ values, particularly of the nonvegetated spoil sample, one series received the theoretical amount of $\mathrm{Ca}(\mathrm{OH})_{2}$ required to neutralize the $\mathrm{pH}$ and the other series received no $\mathrm{Ca}(\mathrm{OH})_{2}$.

In the absence of $\mathrm{Ca}(\mathrm{OH})_{2}$, nitrification failed to take place in the nonvegetated spoil samples, even after 159 days of incubation, but was beginning in the vegetated spoil and undisturbed soil samples after 97 days incubation. In the presence of $\mathrm{Ca}(\mathrm{OH})_{2}$, however, all samples were capable of nitrifying the ammonium of added ammonium sulfate. The lag period preceding the appearance of nitrates in the series with added $\mathrm{Ca}(\mathrm{OH})_{2}$ ranged from 25 days incubation with the vegetated spoil samples to 97 days with the nonvegetated spoil samples. 


\section{Bibliography}

1. Allison, F. E., and Sterling, L. D. "Nitrate Formation From Soil Organic Matter in Relation to Total Nitrogen and Cropping Practices." Soil Sci., Vol. 67 (1949), pp. 239-252.

2. Cornfield, A. H., "The Mineralization of the Nitrogen of Soils During Incubation: Influence of $\mathrm{pH}$, Total Nitrogen, and Organic Carbon Content." Jour. Sci. Food Agr., Vol. 3 (1952), pp. 343-349.

3. Coville, F. V., The Agricultural Utilization of Acid Lands by Acid-Tolerant Crops. U.S.D.A. Bul. No. 6 (1913).

4. Dunn, L. E., "Lime Requirement Determination of Soil by Means of Titration Curves." Soil Sci., Vol. 56 (1943), pp. 341-351.

5. Dorsey, H., Some Effects of Limestone and Hydrated Lime on Biochemical Activities in Acid Soils. Conn. Agr. Exp. Sta. Bull. 141 (1926).

6. Fraps, G. S., Nitrification in Texas Soils. Texas Agr. Exp. Sta. Bull. 259, (1920).

7. Melin, E., "Investigations of the Significance of Tree Mycorrhiza: An EcologicalPhysiological Study." Gustav Fisher (Jena). (1925). Translated by Paul W. Stickel, U.S.D.A. Forest Service. (1930). Burgess Bros., Ann Arbor, Michigan.

8. Pulley, H. C., "Ammonification of Nitrogenous Substances by Pure Cultures of Microorganisms." Jour. Agr. Res., Vol. 42 (1931), pp. 791-800.

9. Russell, J., "The Microorganic Populations of the Soil." The Rothamsted Monographs on Agricultural Science, (1923). Longmans, Grcen and Co., N.Y.

10. Stevenson, I. L., and Chase, F. E., "Nitrification in an Orchard Soil Under Three Cultural Practices." Soil Sci. Vol. 76 (1953), pp. 107-117.

11. Tyner, E. H., and Smith, R. M., "The Reclamation of the Strip-Mined Coal Lands of West Virginia With Forest Species." Soil Sci. Amer. Proc., Vol. 10 (1945), pp. $429-436$.

12. Tyner, E. H., Smith, R. M., and Galpin, S. L., "Reclamation of Strip-Mined Areas of West Virginia." Jour. Amer. Soc. Agron., Vol. 40 (1948), pp. 313-323.

13. Waksman, S. A., Soil Microbiology. John Wiley \& Sons, Inc. N.Y. (1952).

I4. Waksman, S. A. and Starkey, R. L., The Soil and the Microbe. John Wiley \& Sons, N.Y. (1931).

15. Walker, R. H., and Brown, P. E., "Nitrification in the Grundy Silt Loam as Influenced by Liming." Jour. Amer. Soc. Agron., Vol. 27 (1935), pp. 356-363.

16. Walker, R. H., Thorne, D. W, and Brown, P. E., "The Numbers of Ammonium Oxidizing Organisms in Soils as Influenced by Soil Management Practices." Jour. Amer. Soc. Agron., Vol. 29 (1937), pp. 854-864.

I7. Wilson, H. A. and Stewart, Gwendolyn. Unpublished data. 

